\title{
SISTEM PERSEDIAAN ALAT TULIS KANTOR SEBAGAI PENUNJANG PENGAMBILAN KEPUTUSAN BAGIAN LOGISTIK DI PERGURUAN TINGGI RAHARJA
}

\author{
Sri Rahayu ${ }^{1}$ \\ Tuti Nurhaeni ${ }^{2}$ \\ Malidah Rohmah ${ }^{3}$ \\ e-mail:srirahayu@raharja.info,tuti@raharja.info
}

Diterima : 30 Oktober 2014 / Disetujui : 26 November 2014

\begin{abstract}
Utilization of a Computerized Information Systems in the universities is very important in this globalization era. With the existence of computerized information systems, processing allcritical data can be arranged neatly so as to facilitate the storage and retrieval of data. Website is one of the media information that is very effective in presenting information, including for the universities. Problems faced by the user on the stationery system at Perguruan Tinggi Raharja is the lack of support system that is able to facilitate the decision to supply stationery. Stationery system is still using semi-computerized system, there are many papers used are inefficient and not optimal in supporting the user to make a decision. This makes the process of data management to be slow, as well as when the supply of information when needed. The methodology used is through a process of interviews and observations to the user to analyze and implement the system. The results of the analysis is described by using the modeling language UML (Unified Modeling Language). Implementation of the final result achieved is the establishment ofa Webbased information systems that is connected to the database server that facilitates data management and generate information as a decision support for the user.
\end{abstract}

Keyword: System, stationery, Efficiency, Decision Support.

\begin{abstract}
ABSTRAK
Pemanfaatan Sistem Informasi yang terkomputerisasi di Perguruan Tinggi sangat penting pada era globalisasi saat ini. Dengan adanya Sistem Informasi yang terkomputerisasi, semua proses pengolahan data penting dapat tersusun dengan rapih sehingga dapat mempermudah dalam penyimpanan dan pencarian data. Website merupakan salah satu media informasi yang sangat efektif dalam menyajikan informasi, termasuk untuk Perguruan Tinggi Raharja. Masalah yang dihadapi user pada sistem persediaan alat tulis kantor (ATK) di Perguruan Tinggi Raharja adalah kurangnya dukungan sistem yang mampu mempermudah dalam mengambil keputusan untuk persediaan alat tulis kantor. Sistem persediaan alat tulis kantor yang ada masih menggunakan sistem semi komputerisasi, masih banyak berkas yang digunakan yang dinilai kurang efisien dan belum optimal dalam mendukung user untuk mengambil keputusan. Hal ini membuat proses pengelolaan data menjadi lambat, begitu pula saat penyediaan informasi saat dibutuhkan. Metodologi yang digunakan yaitu melalui proses wawancara dan observasi langsung kepada user untuk menganalisa dan mengimplementasikan Sistem. Hasil analisa digambarkan dengan menggunakan bahasa pemodelan UML (Unified Modelling Language). Implementasi berupa hasil akhir yang dicapai yaitu terbentuknya suatu sistem informasi berbasis Web
\end{abstract}


yang dikoneksikan dengan database server yang memudahkan pengelolaan data dan menghasilkan informasi sebagai penunjang keputusan user.

Kata kunci : Sistem, ATK, Efisiensi, Penunjang Keputusan

\section{PENDAHULUAN}

Pemanfaatan Sistem Informasi yang terkomputerisasi di Perguruan Tinggi sangat penting pada era globalisasi saat ini. Dengan adanya Sistem Informasi yang terkomputerisasi, semua proses pengolahan data penting dapat tersusun dengan rapih sehingga dapat mempermudah dalam penyimpanan dan pencarian data. Website merupakan salah satu media informasi yang sangat efektif dalam menyajikan informasi, termasuk untuk Perguruan Tinggi Raharja.

Alat tulis kantor atau yang biasa disingkat dengan ATK, merupakan suatu kebutuhan yang harus dipenuhi karena dapat membantu kegiatan operasional bagian logistik di Perguruan Tinggi Raharja. Dengan semakin berkembangnya Perguruan Tinggi Raharja, sehingga bertambah pula kebutuhan yang harus dipenuhi akan permintaan alat tulis kantor, penggunaan sistem manual tidak lagi efektif dan efisien sehingga user sering menghadapi masalah dalam pengambilan keputusan akan persediaan barang. Secara umum dalam aktivitasnya membuat laporan persediaan alat tulis kantor pada Perguruan Tinggi Raharja menerapkan sistem semi komputerisasi, dalam menyajikan laporan tersebut penggunaan komputer masih belum optimal, sehingga didalam menghasilkan seluruh laporan yang akurat dan tepat menjadi relatif lama. Untuk merubah keadaan tersebut maka perlu adanya suatu sistem informasi yang mendukung untuk mempercepat dan mempermudah laporan persediaan alat tulis kantor bagian logistik pada Perguruan Tinggi Raharja.

\section{PERMASALAHAN}

Masalah yang dihadapi user pada sistem persediaan alat tulis kantor di Perguruan Tinggi Raharja adalah kurangnya dukungan sistem yang mampu mempermudah dalam mengambil keputusan untuk persediaan alat tulis kantor. Sistem persediaan alat tulis kantor yang ada masih menggunakan sistem semi komputerisasi, masih banyak berkas yang digunakan yang dinilai kurang efisien dan belum optimal dalam mendukung user untuk mengambil keputusan. Misalnya saat user akan menambahkan persediaan stok barang, serta saat user akan memenuhi permintaan alat tulis kantor setiap divisi pada perguruan tinggi raharja. Hal ini membuat proses pengelolaan data menjadi lambat, begitu pula saat penyediaan informasi saat dibutuhkan.

\section{METODE PENELITIAN}

Setiap data terkait alat tulis kantor yang di input akan terekam menjadi sebuah data yang terupdate secara otomatis sehingga informasi dapat diberikan secara cepat, tepat dan akurat sehingga memungkinkan sistem untuk memberikan informasi yang merupakan kebutuhan user yang dalam hal ini adalah bagian logistik. Sistem membutuhkan data untuk diolah sehingga menghasilkan informasi yang sesuai dengan yang dibutuhkan. Adapun informasi yang dibutuhkan adalah informasi pendukung pengambilan keputusan bagi user tentang alat tulis kantor pada Perguruan Tinggi untuk pengadaan akan barang-barang tersebut di waktu yang tepat Dengan ketepatan waktu dan informasi sehingga tidak terjadi penumpukkan barang ataupun 
kekurangan barang seperti system manual yang terjadi saat ini dikarenakan informasi yang terima berdasarkan data yang diolah secara manual.

\section{A. Metode Pengumpulan Data}

Terdapat beberapa metode pengmpulan data. Metode pengumpulan data disesuaikan dengan jenis data yang akan dikumpulkan yaitu teknik untuk pengumpulan data primer dan teknik untuk pengumpulan data sekunder.

Pengumpulan data primer pada penelitian ini dilakukan dengan metode survei. Metode survei adalah metode pengumpulan data primer yang menggunakan pertanyaan lisan dan tulisan dari pihak user selaku stakeholder. Metode ini memerlukan adanya kontak atau hubungan antara peneliti dengan subyek (responden) penelitian. Untuk memperoleh data yang diperlukan, dilakukan melalui wawancara dengan stakeholder.

\section{B. Metode Penelitian}

Dari penelitin ini, metode penelitian yang dipakai peneliti dalam melakukan analisa pada Perguruan Tinggi Raharja adalah sebagai berikut :

- Mempelajari prosedur-prosedur operasional yang berlaku pada Perguruan Tinggi Raharja terkait dengan proses persediaan barang.

- Mempelajari aktivitas dan kegiatan persediaan barang di Perguruan Tinggi Raharja.

- Mempelajari dokumen-dokumen lainnya yang didapat dari Perguruan Tinggi Raharja.

- Meninjau kekurangan dan kelemahan sistem yang sedang berjalan. Apakah sistem yang berjalan sudah optimal dan mendukung efisiensi kinerja bagian logistik,
- Membuat rancangan awal (rancangan umum) untuk Perguruan Tinggi Raharja, yang selanjutnya akan dipakai sebagai acuan untuk merancang sistem informasi alat tulis kantor (ATK) pada perguruan Tinggi Raharja.

\section{LITERATURE REVIEW}

Beberapa penelitian sebelumnya ada yang membahas perihal jquery, system informasi berbasis web dan sebagainya. Agar pengembangan system informasi kesiswaan ini dapat dilakukan dengan optimal, perlu adanya studi pustaka sebagai salah satu penerapan metode penelitian. Perlu adanya identifikasi kesenjangan (identify gaps), menghindari pembuatan ulang, mengidentifikasi metode yang pernah dilakukan ataupun penelitian yang mengembangkan penelitian sebelumnya, mengetahui orang lain yang memiliki spesialisasi serta penelitian sebelumnya sama. Beberapa Literature Review tersebut antara lain :

1. Penelitian yang dilakukan oleh Deny Widia Nugraha dari jurnal Mektek Universitas tadulako Palu pada tahun 2012 yang berjudul "Membangun Sistem Informasi Pengelolaan Alat Tuis Kantor (ATK) Berbasis Web”. Penelitian ini menjelaskan perihal Penelitian ini bertujuan untuk membangun sistem informasi manajemen alat tulis kantor berbasis web yang diharapkan membantu mempercepat proses pelaporan penggunaan alat tulis, dan mengurangi kesalahan informasi yang akan menghasilkan laporan yang dapat dipertanggungjawabkan. Berdasarkan hasil pengujian dapat dibuktikan bahwa sistem informasi manajemen berbasis web alat tulis kantor yang dibangun berjalan 
dengan baik, hal ini ditandai dengan menu yang ada untuk bekerja dengan baik, data yang dimasukkan ke dalam database disimpan dengan benar, dan aplikasi update, insert, dan select database sudah dikoneksikan dengan baik juga.

2. Penelitian yang dilakukan oleh Desi Hestya Nugraheni, Adian Fatchur Rochim, Aghus Sofwan dari eprints undip journal Universitas Diponegoro pada tahun 2011 yang berjudul "Sistem Alat Tulis Kantor Di Jurusan Teknik Elektro Universitas Diponegoro". Penelitian ini menjelaskan perihal sistem pencatatan alat tulis kantor di Jurusan Teknik Elektro Universitas Diponegoro yang masih bersifat manual baik dalam proses pemesanan, perhitungan stok, maupun laporan bulanan. Dengan demikian melalui tugas akhir ini akan dibuat suatu aplikasi yang mampu mengatasi hal tersebut. Sistem Informasi Alat Tulis Kantor ini berfungsi sebagai media yang memungkinkan dosen untuk mengadakan permintaan alat dan bahan, dan memudahkan petugas TU untuk mengelola ketersediaan alat dan bahan baik dari segi perhitungan stok maupun laporan-laporan yang dibutuhkan.

3. Penelitian yang dilakukan oleh Dian Susanto, Asep Deddy Supriatna, Erwin Gunadhi dari Jurnal Algoritma Sekolah Tinggi Teknologi Garut pada tahun 2012 yang berjudul "Sistem Pengelolaan Data Transaksi Penjualan Alat Tulis Kantor dan Jasa Photo Copy secara Kredit di PD.Azka Garut". Penelitian ini menjelaskan perihal merancang sistem informasi pengelolaan data transaksi penjualan alat tulis kantor dan jasa photo copy secara kredit di PD. Azqa.
Metodologi yang digunakan dalam pengembangan sistem informasi ini menggunakan Siklus Hidup Pengembangan Sistem (Waterfall). Sistem pengelolaan data transaksi secara kredit yang selama ini berjalan diperusahaan tersebut masih bersifat manual. Sistem manual yang berjalan masih belum bisa memberikan pelayanan yang maksimal, terbukti dengan masih munculnya beberapa permasalahan, diantaranya kesulitan dalam proses pencarian data transaksi pelanggan dan juga pengolahan dalam pembuatan laporan bulanan. Solusi yang diharapkan mampu mengatasi permasalahan tersebut adalah dengan megembangkann sebuah sistem informasi berbasis komputerisasi. Pengembangan sistem informasi ini menggunakan metode traditional system development dengan dibantu oleh beberapa pemodelan sistem seperti : block diagram, flow map, data flow diagram, kamus data, dan entity relationship diagram. Dengan adanya sistem informasi ini maka dapat membantu dalam proses pengelolaan data transaksi secara kredit menjadi lebih baik.

4. Penelitian yang dilakukan oleh Mohammad Subekti, Raden Bagus Rhesa Dharma Widjaya, Eileen Heriyanni, Giovani Dewi dari ComTech Journal Universitas Bina Nusantara pada tahun 2011 yang berjudul "Analisis Dan Perancangan Sistem Informasi Eksekutif Pemasaran Pada Distributor Alat Tulis Kantor". Penelitian ini menjelaskan perihal Sistem informasi eksekutif (SIE) telah banyak digunakan dalam perusahaan dan institusi untuk membantu para eksekutif mengambil keputusan 
secara cepat dan akurat bagi kebutuhan bisnis organisasi. Untuk membuat sebuah sistem informasi eksekutif pemasaran bagi eksekutif Benza Prima sebuah penelitian dilakukan. Sistem informasi eksekutif pemasaran dirancang dapat menghasilkan laporan yang bersifat analitik dan laporan perbandingan dalam bentuk pivot tabel dan grafik untuk analisis pemasaran. Fact finding techniques digunakan untuk mencari informasi dengan melakukan survei langsung ke perusahaan untuk mempelajari kebutuhan perusahaan dan prosedur berjalan. Perancangan sistem informasi eksekutif menggunakan metode Object Oriented Analysis and Design (OOAD). Penelitian ini menghasilkan suatu laporan bagi eksekutif Benza Prima dalam bentuk pivot tabel dan grafik yang dapat membantu eksekutif melakukan pengambilan keputusan. Sistem informasi eksekutif pemasaran yang dirancang diharapkan dapat memberikan informasi analitik kepada eksekutif Benza Prima dalam melakukan perencanaan strategi pemasaran.

5. Penelitian yang dilakukan oleh Purwoko dari commit Journal Universitas Bina Nusantara pada tahun 2010 yang berjudul "Perancangan Sistem Informasi Akuntansi Pembelian dan Persediaan". Penelitian ini menjelaskan perihal Pembelian dan persediaan yang merupakan kegiatan yang harus diperhatikan oleh perusahaan. Oleh karena itu, tujuan penulisan ini adalah untuk merancang sistem informasi akuntansi pembelian dan persediaan alat tulis kantor yang dapat membantu dalam perencanaan dan pengambilan keputusan yang cepat dan tepat. Metodologi yang digunakan untuk mengumpulkan data dan informasi yang diperlukan adalah library research dan field research. Metodologi analisis dan perancangan yang digunakan adalah analisis dengan menggunakan Object Oriented Analysis and Design. Darihasil observasi diperoleh hasil bahwa pencatatan transaksi pada perusahaan ini masih manual dan tidak efisien dalam hal pencatatan barang masuk dan keluar. Simpulan yang dapat diambil yaitu bahwa sistem informasi pembelian dan persediaan yang terkomputerisasi dapat membantu pihak manajemen dalam mengurangi kesalahan dan meningkatkan efektivitas sistem yang ada.

\section{PEMBAHASAN}

A. Use Case Diagram Sistem Informasi Persediaan Alat Tulis Kantor (ATK).

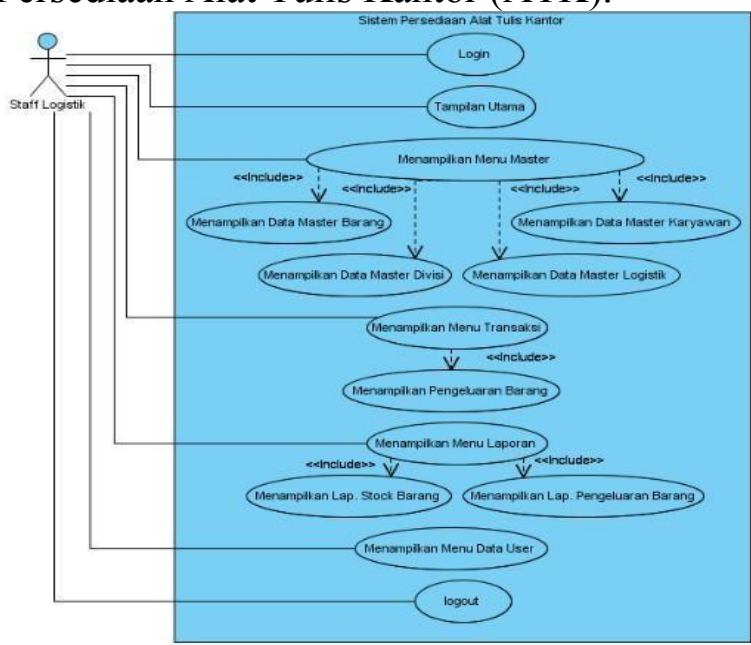

Gambar 1. Use Case Diagram Sistem Informasi Persediaan ATK

Dari hasil penelitian yang dilakukan dapat direpresentasikan dalam bentuk Use case Diagram dibawah ini. Dimana digambarkan apa saja yang dilakukan oleh 
user yang dalam hal ini adalah bagian logistic pada system Persediaan ATK. Terdapat menu transaksi pada system sehingga secara otomatis system akan menampilkan informasi pengeluaran barang. Pengeluaran barang yang terjadi akan secara otomatis pula meng-update ketersediaan barang yang ada pada menu laporan stok barang dan menu laporan pengeluaran barang. Dengan kemudahan dan ketepatan informasi yang diterima bagian logistic menjadikan kemudahan baginya untuk mengambil keputusan barang-barang ATK apa saja yang akan dibeli untuk persedian sebulan kedepan. Lihat gambar pada Gambar 1 .

B. Activity Diagram Sistem Informasi Persediaan ATK

Pada Activity diagram ini menggambarkan proses-proses dan jalur aktivitas dari mulai login sebagai user yang diberikan hak akses, lalu tampilan menumenu yang menampilkan tempat input data sampai dengan laporan keluarnya informasi yang dibutuhkan user. Lihat gambar pada Gambar 2.

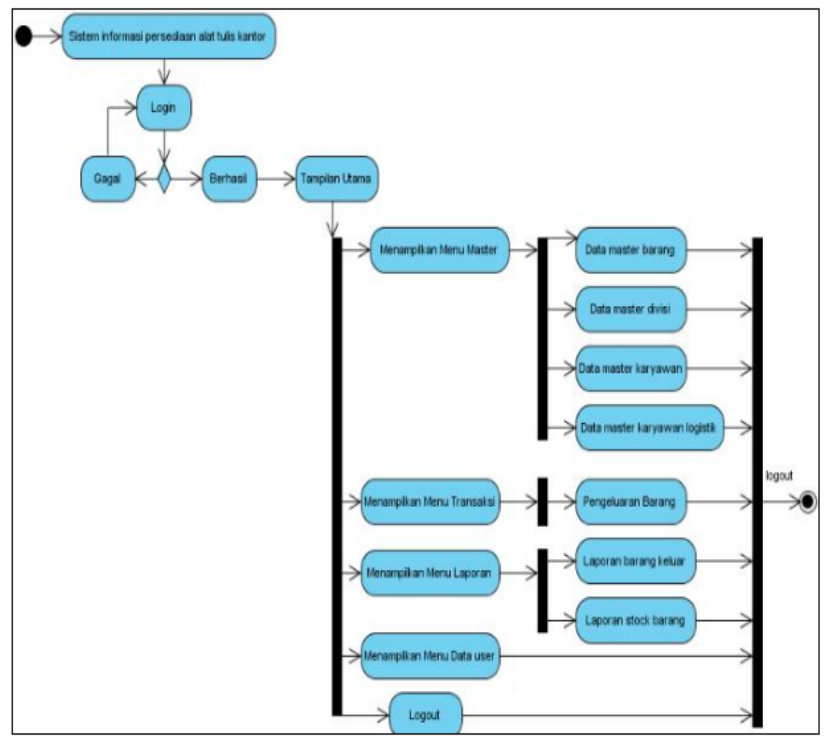

Gambar 2. Activity Diagram Sistem Informasi Persediaan ATK
C. Sequence Diagram Sistem Informasi Persediaan ATK

Sequence Diagram Sistem Informasi Persediaan ATK menggambarkan keterkaitan antar objek dan relevansinya terhadap actoraktor yang terkait dengan system. Lihat gambar pada Gambar 3.

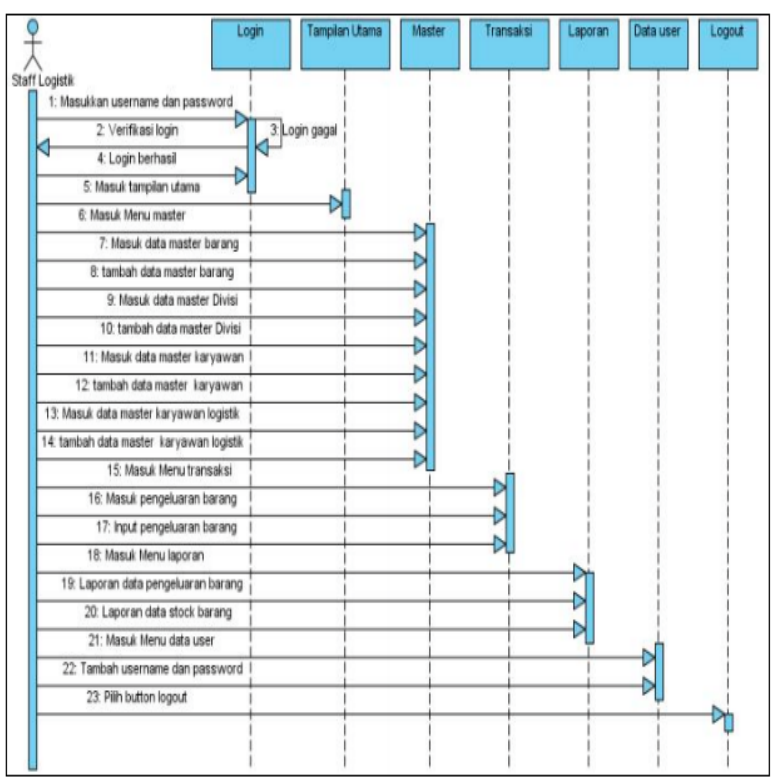

Gambar 3. Sequence Diagram Sistem Informasi Persediaan ATK

D. Class Diagram Sistem Informasi Persediaan ATK

Class diagram merupakan diagram yang selalu ada di permodelan sistem berorientasi objek. Class diagram adalah sebuah spesifikasi yang jika diintansiasi akan menghasilkan sebuah objek dan merupakan inti dari pengembangan dan desain berorientasi objek. Class diagram menunjukkan hubungan antar class dalam sistem yang sedang dibangun dan bagaimana mereka saling berkolaborasi untuk mencapai suatu tujuan.

Sebuah Sistem Informasi dikatakan sesuai dengan parameternya jika informasi yang dihasil bisa cepat, akurat dan timelines. Keakuratan informasi yang dihasilkan jika 
pengolahan database sudah diolah sesuai dengan kaidahnya.

Pada class diagram Sistem Informasi Persediaan ATK ini terdapat 6 tabel, yang terdiri dari4 tabel utama dan 2 tabel operasional yang berelasi sehingga pengolahannya menghasilkan informasi yang dinamis sesuai kebutuhan user.

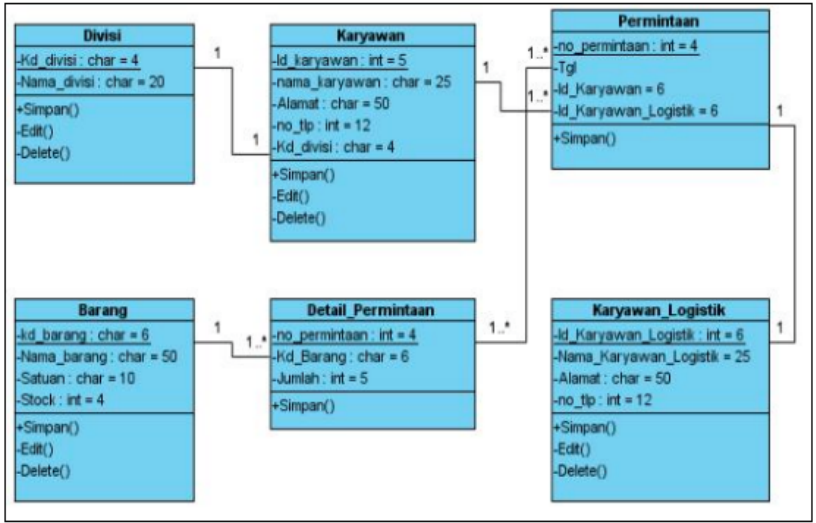

Gambar 4. Class Diagram Sistem Informasi Persediaan ATK

\section{IMPLEMENTASI}

Setelah membuat rancangan database, langkah selanjutnya adalah membuat rancangan tampilan Sistem konversi berbasiS web. Rancangan tampilan aplikasi dibuat dengan menggunakan Macromedia Dreamweaver dan program aplikasi PHP, dikoneksikan dengan database.

Merancang aplikasi dengan program open source (PHP) akan mempermudah pengembangannya karena bisa dijalankan di berbagai platform. Penggunaan konsep database memberikan kemudahan, termasuk juga pada proses pencarian data sampai menghasilkan informasi yang sesuai kebutuhan bagian logistic sehingga dengan dukungan informasi yang tepat dapat diambil keputusan yang tepat juga.

Berikut tampilan dari Sistem Informasi Persediaan ATK.

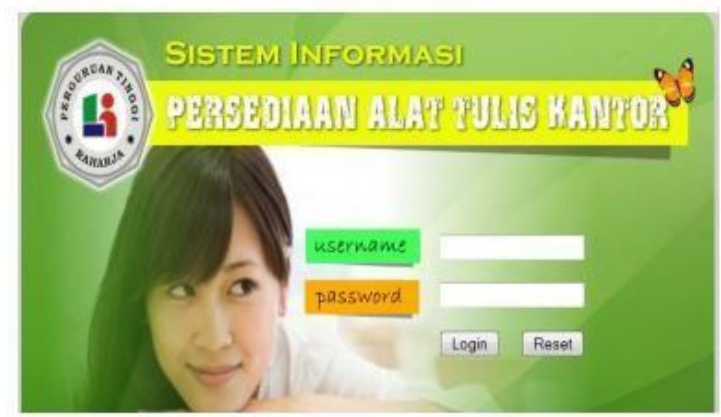

Gambar 5. Tampilan Login

Setelah user melakukan login, maka ditampilkan menu utama dari Sistem Informasi Persediaan ATK seperti pada Gambar 6 dibawah ini.

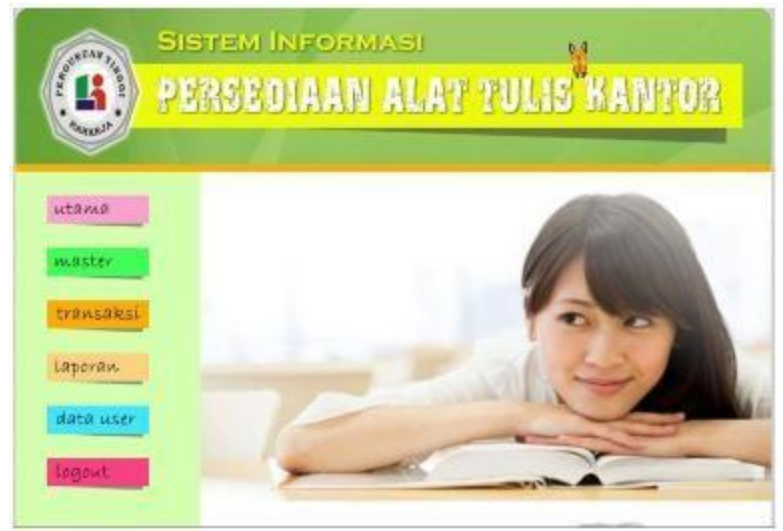

Gambar 6. Tampilan Menu Utama

Berikut ini beberapa Gambar yang ditampilkan sebagai menu bagi system administrator yang mengelola system informasi ATK secara keseluruhan. 


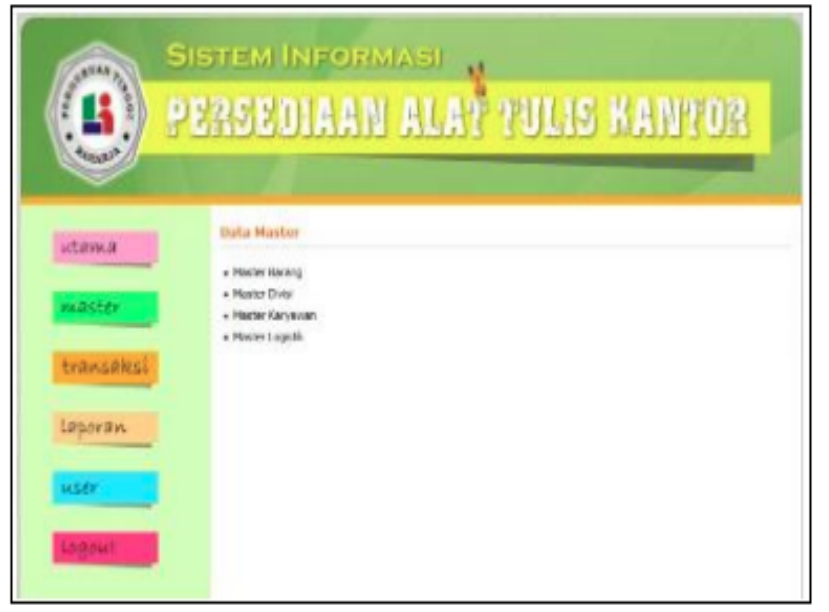

Gambar 7. Tampilan Menu Master

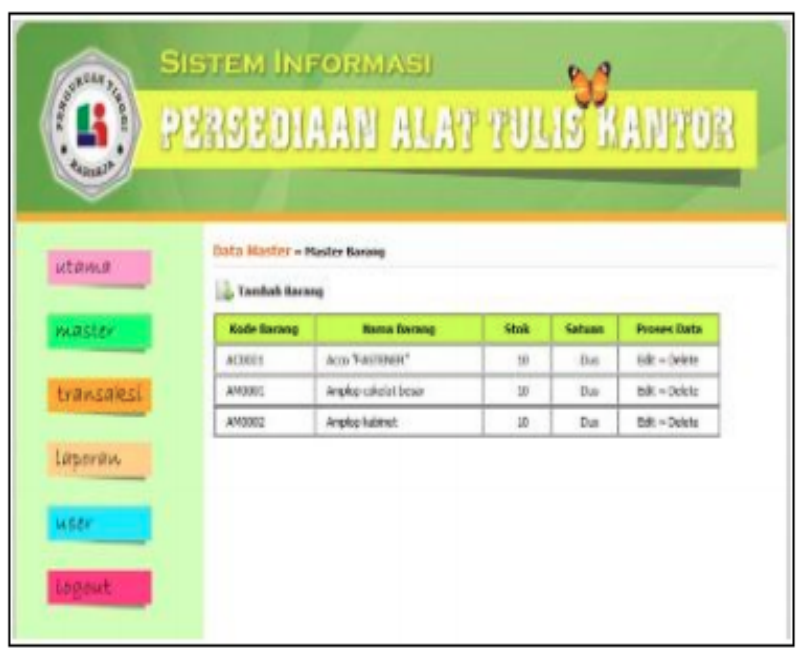

Gambar 8. Tampilan Menu Data Master Barang

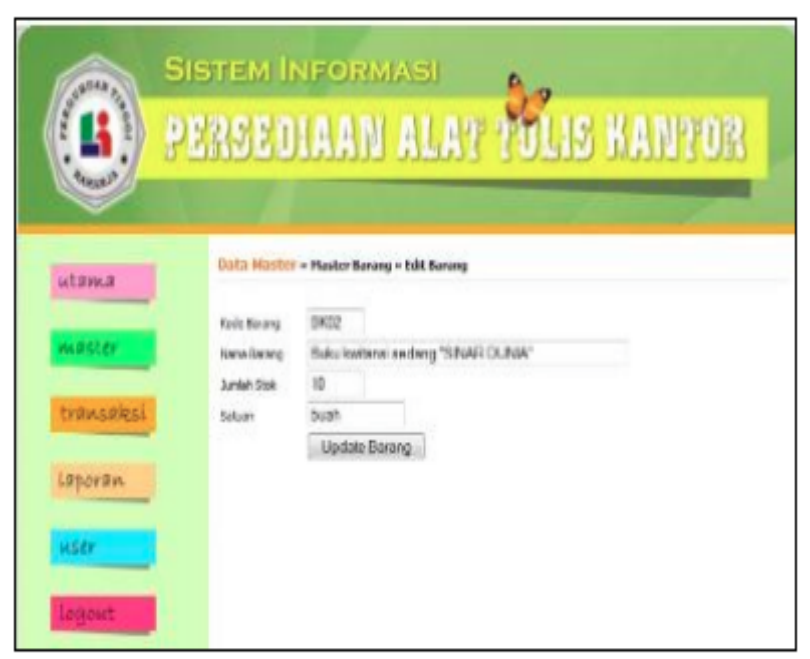

Gambar 9. Tampilan Menu Tambah Data Master Barang

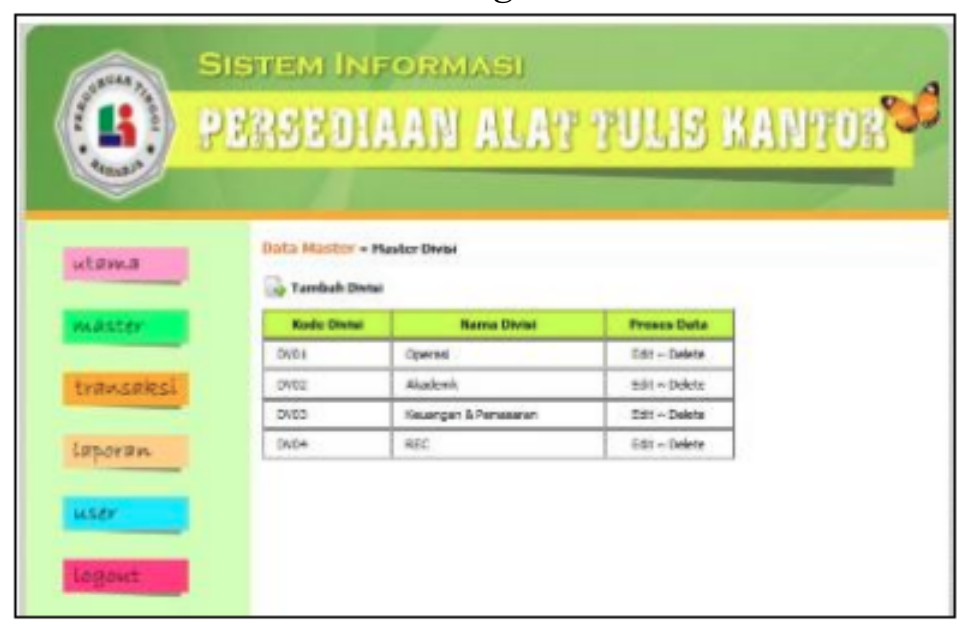

Gambar 10. Tampilan Menu Data Master Divisi

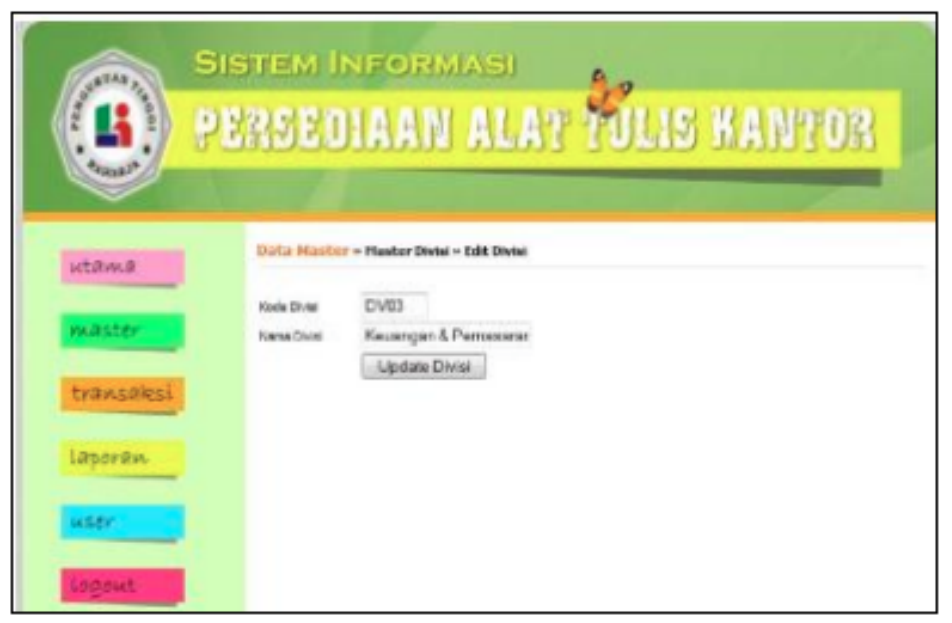

Gambar 11. Tampilan Menu Tambah Data Master Divisi

Pada Gambar 12 menampilkan semua data karyawan dan semua divisi sebagai bagian yang dilayani (pengguna atau pemakai barang). 
ISSN : 1978 - 8282

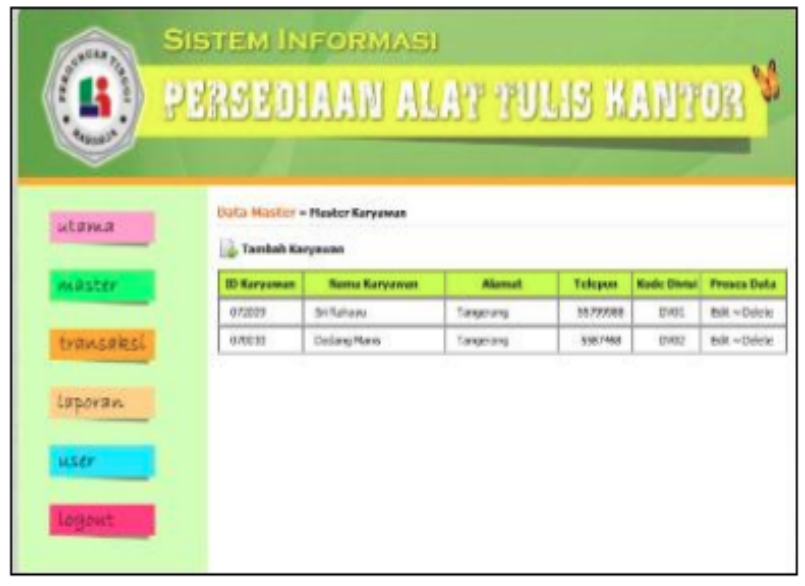

Gambar 12. Tampilan Menu Data Master Karyawan

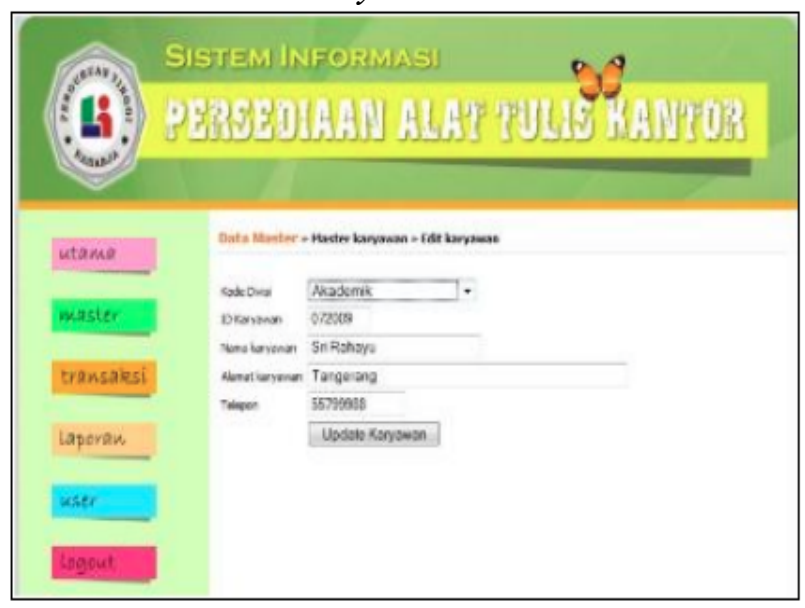

Gambar 13. Tampilan Menu Tambah Data Master Karyawan

Pada Gambar 14 menampilkan data khusus untuk karyawan bagian logistic.

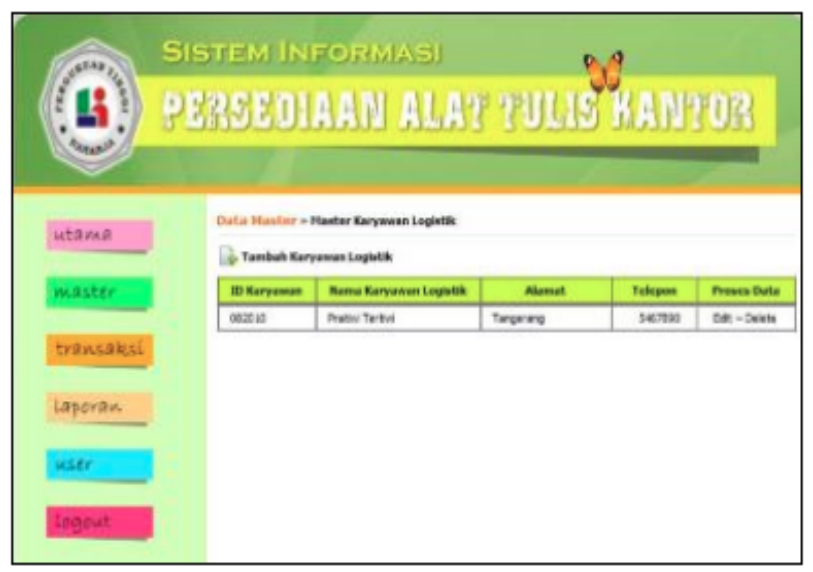

Gambar 14. Tampilan Menu Data Master Karyawan Logistik

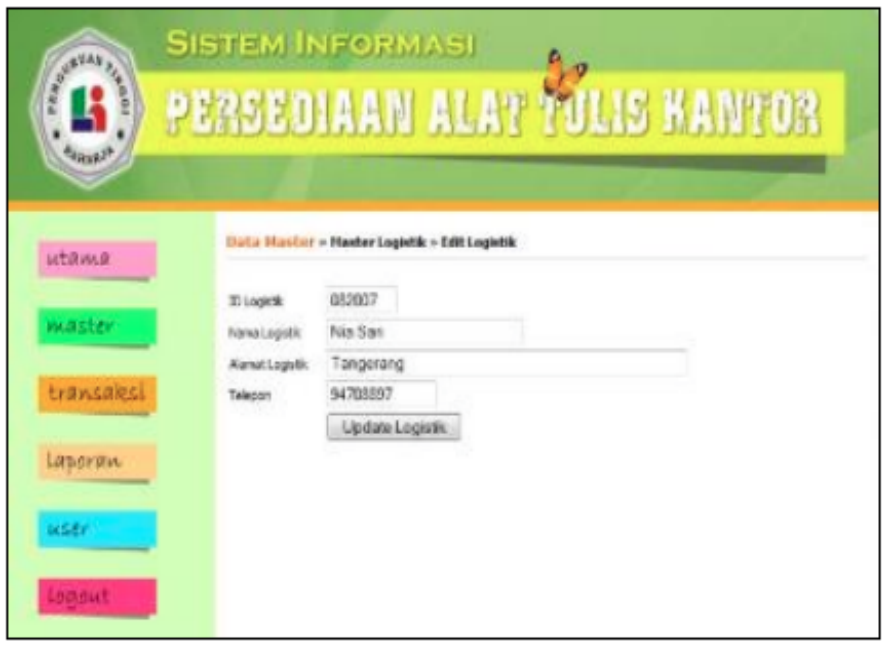

Gambar 15. Tampilan Menu Tambah Data Master Karyawan Logistik

Berikut pada Gambar 16 menampilkan data transaksi otomatis keluar masuknya barang di logistik.

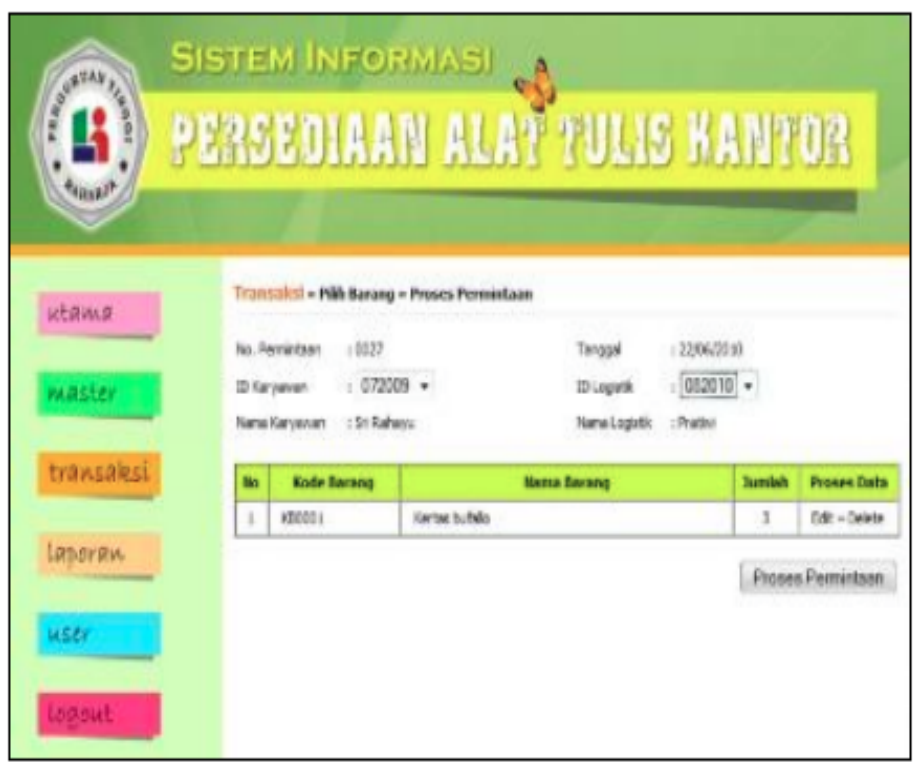

Gambar 16. Tampilan menu Transaksi

Tampilan akhir adalah menu laporan. Informasi berupa laporan merupakan generalisasi dari transaksi yang terjadi dari setiap permintaan dari divisi-divisi lainnya, informasi yang ditampilkan sesuai dengan tanggal atau waktu sesuai dengan keinginan user. Berikut ditampilkan pada Gambar 17. 


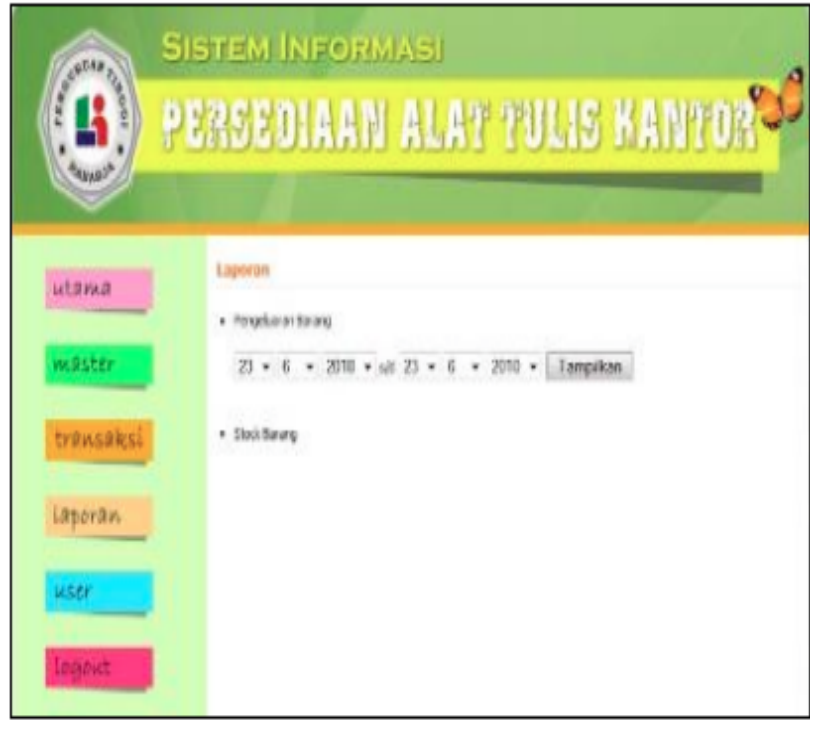

Gambar 17. Tampilan menu Laporan

\section{KESIMPULAN}

Dalam menyajikan laporan Persediaan Alat Tulis Kantor penggunaan komputer yang masih menggunakan aplikasi Ms. Excel belum bisa menghasilkan seluruh laporan yang akurat dan cepat, hal ini mengakibatkan penumpukan barang yang jarang digunakan ataupun kekosongan barang yang diperlukan. Masalah ini dapat dipecahkan dengan adanya rancangan sistem informasi persediaan alat tulis kantor pada Perguruan Tinggi Raharja berbasis web yang dapat memberikan pelayanan informasi yang akurat, tepat waktu dan sesuai dengan kebutuhan yang diinginkan bagian logistik maupun divisi lainnya sebagai pengguna barang. Sistem yang belum terkomputerisasi belum bisa menghasilkan laporan yang efisien karena pengolahan datanya belum tersimpan dalam database server sehingga pekerjaan dilakukan berulang-ulang. Dengan sistem informasi Persediaan Alat Tulis Kantor setiap transaksi yang terjadi setiap harinya secara otomatis digeneralisasi ke laporan dengan cepat dan akurat. Dengan kecepatan dan keakuratan informasi yang diterima bagian logistic perihal laporan stock barang ini menjadikan kemudahan baginya untuk mengambil keputusan barang-barang ATK apa saja yang akan dibeli untuk persedian bulan berikutnya. Selain itu, kemudahan lainnya adalah dalam memenuhi permintaan barang setiap divisi perguruan tinggi raharja dapat direalisasikan karena stok barang tersedia.

\section{DAFTAR PUSTAKA}

1. Augury El Rayeb,dkk. "Optimalisasi Data Warehouse Indeks Kehadiran Mahasiswa Untuk Menunjang Keputusan Pimpinan Perguruan Tinggi. Jurnal Eksplora Informatika, Bali, 2011.

2. Deny Widia Nugraha. Membangun Sistem Informasi Pengelolaan Alat Tuis Kantor (ATK) Berbasis Web. Diakses pada tanggal 18 november 2014 dari :http://jurnal.untad.ac.id/jurnal/index. php/Mektek/article/view/1033/828

3. Dian Susanto, Asep Deddy Supriatna, Erwin Gunadhi. Sistem Pengelolaan Data Transaksi Penjualan Alat Tulis Kantor dan Jasa Photo Copy secara Kredit di PD.Azka Garut.Diakses pada tanggal 18 november 2014 dari : http://jurnal.sttgarut.ac.id/index.php/a lgoritma/article/view/30/31

4. Desi Hestya Nugraheni, Adian Fatchur Rochim, Aghus Sofwan. Sistem Alat Tulis Kantor Di Jurusan Teknik Elektro Universitas Diponegoro. Diakses pada tanggal 18 november 2014 dari : http://eprints.undip.ac.id/25215/1/ML 2F305201.pdf

5. Gunawan Ali. "Sistem Pendukung Keputusan Penentuan Jabatan Struktural Menggunakan Metode Promethee". Jurnal Eksplora Informatika, 2013. 
6. Muhamad Yusup,dkk. "GO+ Dalam Menunjang Int+ Untuk Pengelolaan Data CMB Pada Perguruan Tinggi". CCIT Journal, 2014.

7. Mohammad Subekti, Raden Bagus Rhesa Dharma Widjaya, Eileen Heriyanni, Giovani Dewi. Analisis Dan Perancangan Sistem Informasi Eksekutif Pemasaran Pada Distributor Alat Tulis Kantor. Diakses pada tanggal 18 november 2014 dari : http://www.qjournal.co.id/paper-

1115- analisis-dan-perancangansistem-informasi-eksekutifpemasaran-pada-distributor-alat-tuliskantor- studi-kasus-pada-benzaprima.html

8. Purwoko. Perancangan Sistem Informasi Akuntansi Pembelian dan Persediaan. Diakses pada tanggal 18 november 2014 dari : http://msi.binus.ac.id/files/2013/05/04 01-10-

Purwoko_Departemen_Keuangan.pdf

9. Untung Rahardja,dkk. "Kinerja iLearning Raharja Ask And News (IRAN) Dalam Mendukung Kegiatan Tri Dharma Iduhelp". CCIT Journal, 2014.

10. Wiranto Herry Utomo. "Pemodelan Basis Data". Penerbit Andi, Yogyakarta, 2010. 